I. Korzhov, P. Shchapov, R. Mygushchenko, O. Kropachek

National Technical University "Kharkiv Polytechnic Institute", Kharkiv, Ukraine

\title{
SPACE OPTIMIZATION MODELS OF INFORMATIVE FEATURES FOR CONTROL AND DIAGNOSTICS OF THE TECHNICAL STATE OF DYNAMIC INDUSTRIAL OBJECTS
}

\begin{abstract}
The problem of improving the effectiveness of information systems for monitoring and diagnosing the technical state of industrial objects with dynamic properties is inextricably linked with the formation of optimal space for informative parameters under which control and diagnostics are carried out. The formation of optimal space of informative parameters for monitoring and diagnosing the technical state of industrial object is the task of evaluation regarding limited volume of measurements and parameters characterizing the dynamics of equipment during the test changes in the technical state of industrial object. In the article the space optimization models of informative features are considered on the maximum probability of control and diagnostics of the technical state of dynamic industrial objects criterion. The article considers space optimization models of informative features based on the maximum probability of control and diagnostics of the technical state of dynamic industrial objects. The complex influence of three parameters (geometric distance between diagnosed states, number of informative parameters, training sample volume) on the probability of control and diagnostics of the technical state of industrial objects is studied. The ability to form optimal, maximum probability of control and diagnostics of the technical state of dynamic industrial objects and the system of informative features is proved.
\end{abstract}

Keywords : technical state; informative features; control; diagnosing.

\section{Introduction}

The problem of improving the effectiveness of information systems for monitoring and diagnosing the technical state of industrial objects with dynamic properties is inextricably linked with the formation of optimal space for informative parameters under which control and diagnostics are carried out [1].

The formation of optimal space of informative parameters for monitoring and diagnosing the technical state of industrial object is the task of evaluation regarding limited volume of measurements and parameters characterizing the dynamics of equipment during the test changes in the technical state of industrial object [2].

The article studies space optimization models of informative features based on the maximum probability of control and diagnostics of the technical state of industrial objects with dynamic properties.

\section{Studying space optimization models of informative features}

Studying space optimization models of informative features based on the maximum probability of control and diagnostics of the technical state of industrial objects was carried out for the function

$$
P_{\text {Д }}=\int_{-\infty}^{\left(\delta^{2} / 2\right) \cdot\left(\delta^{2}+2 p / N\right)^{-1 / 2}} e^{-\frac{t^{2}}{2}} d t,
$$

where $\delta$ - geometric distance between diagnosed states, $p$ - number of informative parameters, $N-$ training sample volume.

Probability $P_{Д}$ is considered as the objective function optimizing the features space, for which the optimal choice of space dimension corresponds to the maximum function $P_{\text {Д }}[3,4]$.
To simulate the influence of space dimension of informative features on the probability of control and diagnostics of the technical state of industrial objects, a cumulative model for the parameter $\delta_{n}$ characterizing the gradual growth of the geometric distance between diagnosed states with increasing size of the space feature $p$ was used:

$$
\delta_{n}=\sum_{k=1}^{p} \frac{a}{k^{2}} .
$$

The variable $a$ used in the model (2) serves as an additional parameter that determines the geometric distance between the diagnosed states for the first, most informative feature.

To reveal the influence of the informative features quality on the optimal dimension of these features, a three-dimensional representation of the equation (1) is used for two variants of the most informative feature:

$a=0.5$ (the feature is not informative, the probability of control and diagnostics is equal to 0.6915);

$a=2$ (the feature is informative, the probability of control and diagnostics is equal to 0.9773 ).

The obtained three-dimensional graphs for the studied probability $P_{\text {Д }}$ of the function $p$ and $N$ for various values $a$ are presented in Fig. 1

Fig. 1 shows that with the growth of the informative features quality (growth $a$ ) with maximum $P_{\text {Д}}$, the space dimension of features increases.

Such influence can additionally be shown by twodimensional dependency graphs $P_{Д}$ for the space dimension of the features for three options of $N$ fixation and parameter $a$ variability (Fig. 2). 

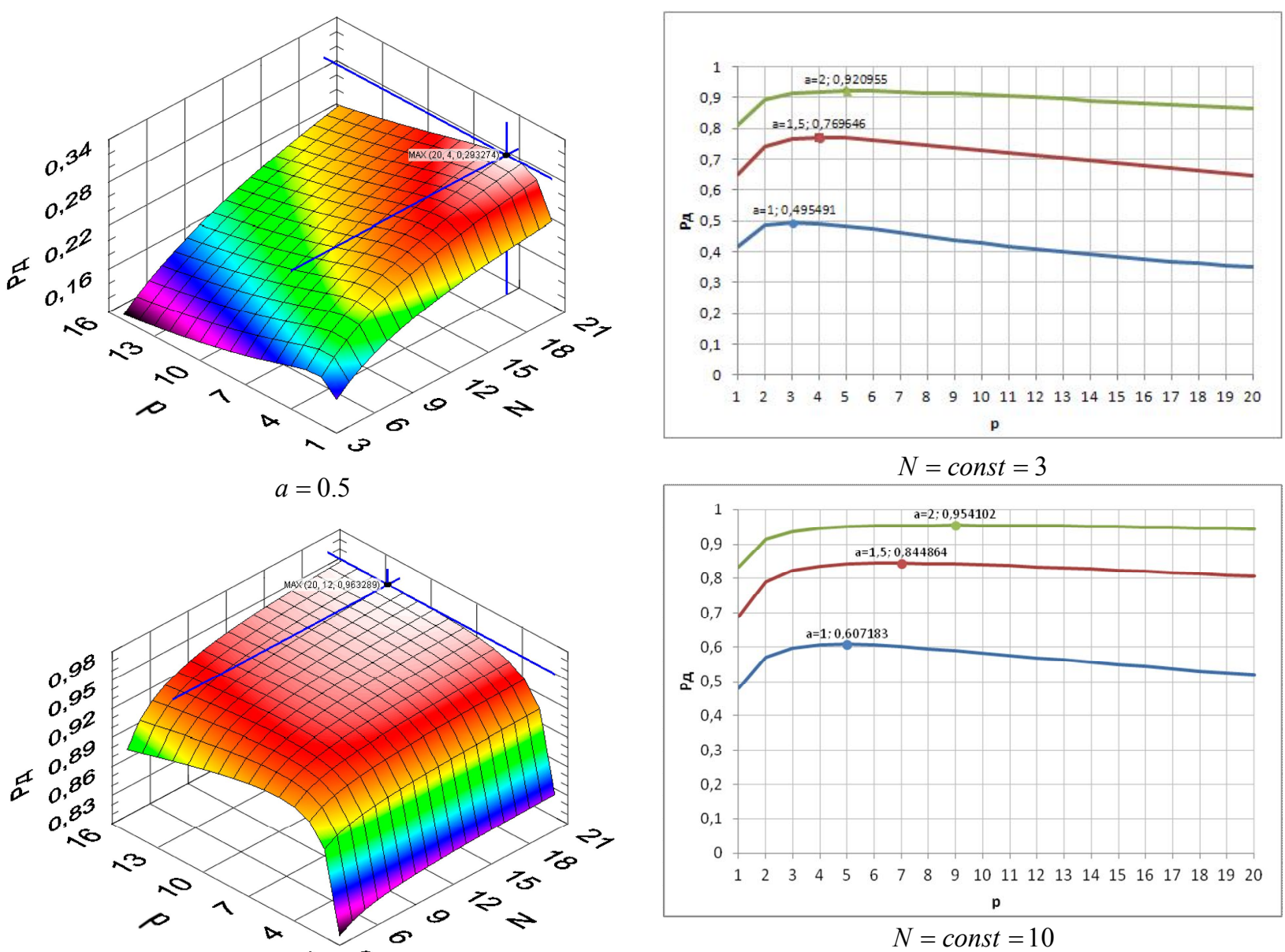

Fig. 2. Two-dimensional dependency graphs $P_{Z}$ for the space dimension of the features for three options of $N$ fixation and

Fig. 1. Three-dimensional graphs for the studied probability $P_{\text {Д }}$ of function $p$ and $N$ for different values $a$

Table 1 was calculated regarding the quantitative analysis of the maximization effect $P_{Д}$ with the optimal space dimension features.

parameter $a$ variability

Table 1 clearly shows how the value of the parameter $a$ affects the maximum $P_{\text {Д }}$, namely with increasing $a$ the maximum $P_{Д}$ always has a tendency to increase.

Table 1 - Value $\boldsymbol{P}_{д}$ and corresponding optimal dimensions for $\boldsymbol{N}$ and parameter $\boldsymbol{a}$ variability

\begin{tabular}{|c|c|c|c|c|c|c|c|c|c|c|}
\hline$a$ & 0.2 & 0.4 & 0.6 & 0.8 & 1 & 1.2 & 1.4 & \begin{tabular}{|l|}
1.6 \\
\end{tabular} & 1.8 & 2 \\
\hline \multicolumn{11}{|c|}{$N=$ const $=3$} \\
\hline $\max P_{Д}$ & 0.029839 & 0.111725 & 0.227322 & 0.361454 & 0.495491 & 0.617448 & 0.72434 & 0.809462 & 0.874264 & 0.920955 \\
\hline$p_{\text {ОП }}$ & 2 & 2 & 2 & 3 & 3 & 4 & 4 & 4 & 5 & 5 \\
\hline \multicolumn{11}{|c|}{$N=$ const $=6$} \\
\hline $\max P_{\text {Д }}$ & 0.041276 & 0.146486 & 0.285090 & 0.429353 & 0.565670 & 0.683076 & 0.779756 & 0.853370 & 0.906933 & 0.943648 \\
\hline$p_{\text {ОП }}$ & 2 & 2 & 3 & 3 & 4 & 4 & 5 & 6 & 6 & 7 \\
\hline \multicolumn{11}{|c|}{$N=$ const $=9$} \\
\hline $\max P_{\text {Д }}$ & 0.049493 & 0.169125 & 0.317002 & 0.464963 & 0.598980 & 0.713058 & 0.803638 & 0.871543 & 0.919751 & 0.952268 \\
\hline$p_{\text {ОП }}$ & 2 & 3 & 3 & 4 & 5 & 5 & 6 & 7 & 8 & 8 \\
\hline \multicolumn{11}{|c|}{$N=$ const $=12$} \\
\hline $\max P_{\text {Д }}$ & 0.056000 & 0.185688 & 0.337600 & 0.487207 & 0.620125 & 0.730721 & 0.817484 & 0.881819 & 0.926961 & 0.956969 \\
\hline$p_{\text {ОП }}$ & 2 & 3 & 4 & 4 & 5 & 6 & 7 & 8 & 9 & 9 \\
\hline \multicolumn{11}{|c|}{$N=$ const $=15$} \\
\hline $\max P_{\text {Д }}$ & 0.061400 & 0.198312 & 0.353817 & 0.502943 & 0.634215 & 0.742476 & 0.826670 & 0.888567 & 0.931637 & 0.960006 \\
\hline$p_{\text {ОП }}$ & 2 & 3 & 4 & 5 & 6 & 7 & 8 & 9 & 9 & 10 \\
\hline
\end{tabular}


End of table 1

\begin{tabular}{|l|l|l|l|l|l|l|l|l|l|l|}
\hline \multicolumn{10}{|c|}{$N=$ const $=18$} \\
\hline $\max P_{\text {Д }}$ & 0.066008 & 0.208315 & 0.366020 & 0.515097 & 0.645043 & 0.751378 & 0.833508 & 0.893504 & 0.934991 & 0.962159 \\
\hline$p_{\text {ОП }}$ & 2 & 3 & 4 & 5 & 6 & 7 & 8 & 9 & 10 & 11 \\
\hline
\end{tabular}

To study the influence of $N$ growth on the probability extremity $P_{Д}$, three variants were chosen for $N(N=3, N=10, N=20)$ (Fig. 3). Fig. 3 clearly shows that when the training sample volume $N$ increases, the probability $P_{Д}$ only increases, at the same time the optimal space dimension of the informative features increases, which is shown by calculations data in Table 2 .

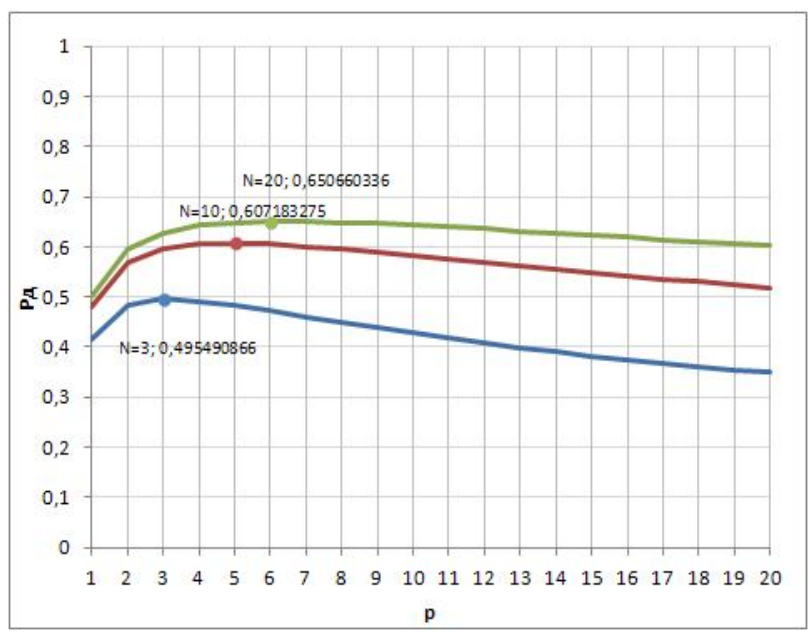

$a=$ const $=1$

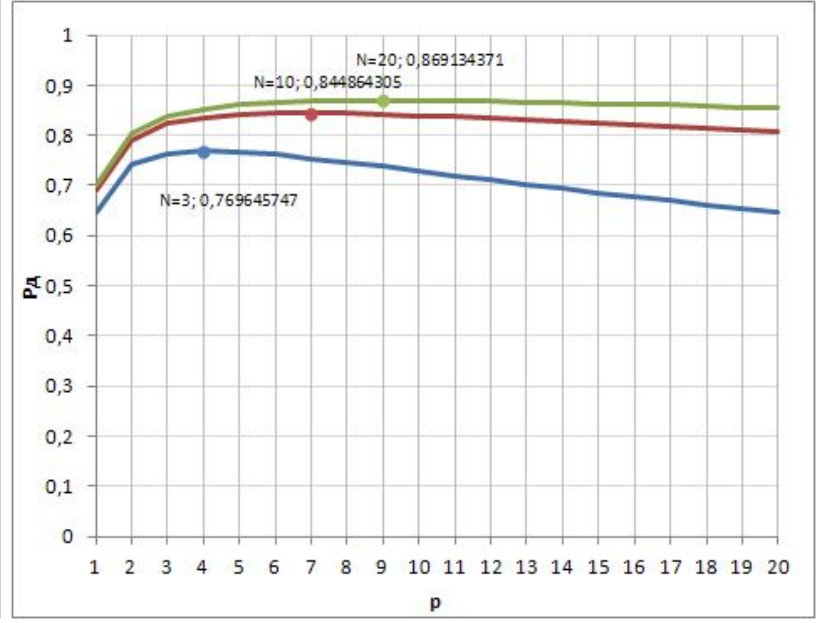

$a=$ const $=1.5$

Fig. 3. Two-dimensional dependency graphs $P_{A}$ for the space dimension of the features for three options of $a$ fixation and parameter $N$ variability

Table 2 - Value $\boldsymbol{P}_{Д}$ and corresponding optimal dimensions for $\boldsymbol{a}$ and parameter $\boldsymbol{N}$ variability

\begin{tabular}{|c|c|c|c|c|c|c|c|c|c|c|}
\hline$N$ & 3 & 6 & 9 & 12 & 15 & 18 & 21 & 24 & 27 & 30 \\
\hline \multicolumn{11}{|c|}{$a=$ const $t=0.2$} \\
\hline $\max P_{\text {Д }}$ & 0.029839 & 0.041276 & 0.049493 & 0.056000 & 0.061400 & 0.066008 & 0.070018 & 0.073555 & 0.076711 & 0.079724 \\
\hline$p_{\text {ОП }}$ & 2 & 2 & 2 & 2 & 2 & 2 & 2 & 2 & 2 & 3 \\
\hline \multicolumn{11}{|c|}{$a=$ const $=0.4$} \\
\hline $\max P_{\text {Д }}$ & 0.111725 & 0.146486 & 0.169125 & 0.185688 & 0.198312 & 0.208315 & 0.216464 & 0.223244 & 0.229001 & 0.234508 \\
\hline$p_{\text {ОП }}$ & 2 & 2 & 3 & 3 & 3 & 3 & 3 & 3 & 4 & 4 \\
\hline \multicolumn{11}{|c|}{$a=$ const $=0.6$} \\
\hline $\max P_{\text {Д }}$ & 0.227322 & 0.285090 & 0.317002 & 0.337600 & 0.353817 & 0.366020 & 0.375550 & 0.383206 & 0.390213 & 0.396145 \\
\hline$p_{\text {ОП }}$ & 2 & 3 & 3 & 4 & 4 & 4 & 4 & 4 & 5 & 5 \\
\hline \multicolumn{11}{|c|}{$a=c o n s t=0.8$} \\
\hline $\max P_{\text {Д }}$ & 0.361454 & 0.429353 & 0.464963 & 0.487207 & 0.502943 & 0.515097 & 0.524330 & 0.532020 & 0.538564 & 0.543973 \\
\hline$p_{\text {ОП }}$ & 3 & 3 & 4 & 4 & 5 & 5 & 5 & 6 & 6 & 6 \\
\hline \multicolumn{11}{|c|}{$a=$ const $=1$} \\
\hline $\max P_{\text {Д }}$ & 0.495491 & 0.565670 & 0.598980 & 0.620125 & 0.634215 & 0.645043 & 0.653111 & 0.659993 & 0.665513 & 0.670143 \\
\hline$p_{\text {ОП }}$ & 3 & 4 & 5 & 5 & 6 & 6 & 6 & 7 & 7 & 8 \\
\hline \multicolumn{11}{|c|}{$a=$ const $=1.2$} \\
\hline $\max P_{\text {Д }}$ & 0.617448 & 0.683076 & 0.713058 & 0.730721 & 0.742476 & 0.751378 & 0.758058 & 0.763550 & 0.767935 & 0.771773 \\
\hline$p_{\text {ОП }}$ & 4 & 4 & 5 & 6 & 7 & 7 & 8 & 8 & 9 & 9 \\
\hline
\end{tabular}




\section{Conclusions}

The use of equation (1) allowed conducting the study of the complex influence of three parameters (geometric distance between diagnosed states, number of informative parameters, training sample volume) on the probability level of control and diagnostics of the technical state of industrial objects. Such research proved the ability to form optimal, maximum probability of control and diagnostics of the technical state of industrial objects with dynamic properties and the system of informative features [5].

\section{REFERENCES}

1. Capenko, M.P. (1985), Izmeritel'nye informacionnye sistemy: Struktury i algoritmy, sistemotehnicheskoe proektirovanie [Measuring information systems: structures and algorithms, systems engineering design], Jenergoatomizdat, Moscow, $440 \mathrm{p}$.

2. Myhushchenko, R.P. (2014), "Issledovanie vlijanija ogranichennosti apriornoj informacii na vid i razmer dostovernosti diagnostiki [The study of the influence of limited a priori information on the type and size of diagnostic accuracy]", Vestnik BGTU im. V. G. Shuhova, BGTU im. V. G. Shuhova, Belgorod, No. 6, pp. 201-204.

3. Myhushchenko R.P. (2015), Metody i prystroi system bahatoparametrovoi funktsionalnoi diahnostyky vibratsiinykh obiektiv (teoretychni osnovy ta vprovadzhennia) [Methods and devices of systems of banatoparametric functional diagnostics of vibration objects (theoretical foundations and implementation)], avtoref. dys. ... dokt. tekhn. nauk : 05.11.13, KhPI, Kharkiv, $32 \mathrm{p}$.

4. Korzhov, I.M., Mygushchenko, R.P., Shchapov, P.V. and Kropachek O.Yu. (2019), "Studying the influence of training sample volume on the average risk of technical diagnostics", International Journal of Engineering Research and Applications (IJERA), Vol. 9 - No. 2 (Feb. 2019).

5. Shhapov, P.F. and Avrunin, O.G. (2011), Povyshenie dostovernosti kontrolja i diagnostiki objektov v uslovijah neopredeljonnosti [Improving the reliability of monitoring and diagnostics of objects under uncertainty], KhNADU, Kharkiv, $191 \mathrm{p}$.

Надійшла (received) 11.01.2019

Прийнята до друку (accepted for publication) 13.03.2019

\section{Моделі оптимізації простору інформативних ознак при контролі та діагностування технічного стану динамічних промислових об'сктів \\ I. М. Коржов, П. Ф. Щапов, Р. П. Мигущенко, О. Ю. Кропачек}

Проблема підвищення ефективності інформаційних систем для моніторингу та діагностування технічного стану промислових об'єктів з динамічними властивостями нерозривно пов'язана 3 формуванням оптимального простору для інформаційних параметрів, за якими здійснюються контроль і діагностика. Формування оптимального простору інформаційних параметрів для моніторингу та діагностування технічного стану промислового об'єкту є завданням оцінки обмеженого обсягу вимірювань та параметрів, що характеризують динаміку обладнання під час тестових змін технічного стану промислового об'єкта. В статті розглянуті моделі оптимізації простору інформативних ознак за критерієм максимуму вірогідності контролю та діагностики технічного стану промислових об'єктів 3 динамічними властивостями. Виконано дослідження моделі оптимізації простору інформаційних ознак на основі отримання максимальної вірогідності контролю та діагностики технічного стану промислових об'єктів. Досліджено комплексний вплив трьох параметрів (геометричної відстані між станами, що діагностуються, кількості інформативних параметрів, обсягу навчальної вибірки) на величину вірогідності контролю та діагностування технічного стану промислових об'єктів. Доведено спроможність формувати оптимальну, за максимумом вірогідності контролю та діагностування технічного стану промислових об'єктів 3 динамічними властивостями, систему інформативних ознак.

Кл юч ов і слов а : технічний стан; інформативні ознаки; контроль; діагностування.

\section{Модели оптимизации пространства информативных признаков \\ при контроле и диагностирования технического состояния динамических промышленных объектов}

И. М. Коржов, П. Ф. Щапов, Р. П. Мигущенко, О. Ю. Кропачек

Проблема повышения эффективности информационных систем для мониторинга и диагностирования технического состояния промышленных объектов с динамическими свойствами неразрывно связана с формированием оптимального пространства для информационных параметров, по которым осуществляются контроль и диагностика. Формирование оптимального пространства информационных параметров для мониторинга и диагностирования технического состояния промышленного объекта является задачей оценки ограниченного объема измерений и параметров, характеризующих динамику оборудования во время тестовых изменений технического состояния промышленного объекта. В статье рассмотрены модели оптимизации пространства информативных признаков по критерию максимума достоверности контроля и диагностики технического состояния промышленных объектов с динамическими свойствами. Выполнено исследование модели оптимизации пространства информационных признаков на основе получения максимальной достоверности контроля и диагностики технического состояния промышленных объектов. Исследовано комплексное воздействие трех параметров (геометрической расстояния между состояниями диагностируемых количества информативных параметров, объема обучающей выборки) на величину достоверности контроля и диагностирования технического состояния промышленных объектов. Доказана способность формировать оптимальную, по максимуму достоверности контроля и диагностирования технического состояния промышленных объектов с динамическими свойствами, систему информативных признаков.

Ключев ы е слов а: техническое состояние; информативные признаки; контроль; диагностирование. 